\title{
METHODOLOGY FOR ASSESSING THE QUALITY OF RAIL CONNECTIONS ON THE NETWORK
}

The role of the EU transport system is to provide a high degree of mobility where necessary, to increase its performance in terms of speed, comfort, and safety. Achieving a consistent, integrated, and efficient transport system currently requires connections linking all transport modes. The most important criteria from the point of view of passengers are the reachability of the destination and frequency. This paper assesses the quality of rail services by considering the supply of connections on the network. It proposes a methodology for evaluating the constructed timetable in passenger traffic for the assessment of the achievability of tariff points. We also present some results of a case study of a Slovakian railway network.

Keywords: Connection, relation, transfers, speed, quality, network.

\section{Introduction}

The EU pays systematic attention to the quality of passenger transport [1], [2] and [3]. Quality is perceived differently by users and transportation service providers or organizers of transport as well as by society. The needs and expectations of customers are met by establishing procedures under the provisions of the Regulation of the European Parliament and Council Regulation (EC) No. 1371/2007 on rail passengers' rights and obligations [4].

The cornerstone of transport services is to provide travel opportunities by creating links and connections. Often, after the introduction of the new timetable under discussion whether it is better or worse, each approach is evaluated in a subjective manner. The authors solved some partially problematic of rail passenger quality services [5], [6], [7], [8], [9] and [10]. At present, there is no methodology for assessing train timetables from the transportation point of view as a whole. We evaluate specific trains and connections in the stations only, but not the quality of the connection from point A to point B.

The aim of this paper is to introduce a new methodology for the assessment of timetables in terms of passenger traffic focused on connectivity and linking. From the passenger's point of view, it is necessary to assess the availability of travelling opportunities between selected points on the rail network. The travel offer from A to B is in principle affected by travel time, number of transfers (changing the transport means), and number of travel opportunities. Connectivity and linking also affect several factors.
This is an outcome for setting of draft criteria for connection evaluation.

Introduced study is designed in purview of the set up a tool for an objective evaluation of the quality of public transport service. Specifically, the aspects of availability and time of the transport services in selected geographical area are closed to the Standard EN 13816 [3].

\section{Selecting a set of tariff points for evaluation}

The aim of the proposed methodology is the comprehensive evaluation of the whole timetable in terms of train passenger services. An ideal case is to evaluate all existing relations between all tariff points for passenger transport on the railway network. If the rail network contains $n$ tariff points for passenger transportation, then the number of sessions to be examined is $m$ :

$m=n^{2}$

For the assessment of connection quality between stations and stops, it is necessary to select a set of representative tariff points which ensures quality assessment on a network-wide scale. For the selection of stations and stops for this sample, it is appropriate to identify specific process steps. Following the individual steps of the proposed procedure, we select tariff points according to the following evaluation criteria:

\footnotetext{
* ${ }^{1}$ Jozef Gasparik, ${ }^{2}$ Jaromir Siroky, ${ }^{1}$ Lumir Peceny, ${ }^{1}$ Martin Halas

'Department of Railway Transport, Faculty of Operation and Economics of Transport and Communications, University of Zilina, Slovakia, E-mail: jozef.gasparik@fpedas.uniza.sk

${ }^{2}$ Transport Faculty Jan Perner, University of Pardubice, Czech Republic
} 
- Demographic and geographic criteria (population criterion, meaning places of importance in public administration and local government),

- Criterion of railway geography (location and importance of stations on the rail network - crossroads, junction stations),

- Criterion of tourist destinations (the inclusion of stations with significant potential inflows of passengers).

\section{Proposed procedure of connection assessment}

The proposed methodology aims to comprehensively cover the possibility of achieving any pair of tariff points by passenger trains on a selected rail network in order to assess the quality of the travel opportunities in this area by using selected indicators [11] and [9].

The methodology is based on the evaluation of defined criteria for connectivity between the selected tariff points on the network. Based on the methodology, we evaluate a particular connection. It is necessary to determine whether the connection is evaluated during the working day or at the weekend. It is also possible to evaluate on a selected working day, Saturday, or Sunday. Consequently, we evaluate the summarizing indicators for services in terms of particular relations within the examined networks.

\subsection{Connection evaluation}

For assessing the connectivity and quality of connections in an examined relation (session), we identify the following factors, some of them are introduced in literature [12] and [13]:

- Number of connections $N_{s}$ during the reporting day, direct connections as well connections with changing (transfers).

- Average waiting time of passenger $W_{i}$. This is the time that the passenger has to wait for connection to a point of departure, possibly a transfer point. It is defined as half of the time between the departure of two successive connections:

$W_{i}=\frac{\left(t_{i+1}-t_{i}\right)}{2}[h]$

where:

$t_{i} \quad$ departure time of train at the boarding station for a rated connection

$t_{i+1}$ departure time of the next train at the boarding station of the next connection

- Distance route of relation $L_{i}$. This is the travel distance by vehicles creating the connection. This criterion is important to calculate transportation speed and the rate of achievement.

- Type and number of trains creating the connection. This factor reflects the quality of transport services on the connection.
In terms of ZSR, the types of trains are EC - EuroCity, IC - InterCity, Ex - Express trains, R - fast trains, $\mathrm{Zr}$ - semi fast trains, and Os - passenger trains.

- Transportation time $T_{p}$. Time between the departure from the boarding station on the route and disembarking the train at the destination railway station (tariff point).

- Number of transfers (changing transport means) $N_{p}$. This is the absolute number of changes of transport vehicles (trains) before reaching the target station.

- Transfer time $T_{w}$. This is the total time that passengers spend waiting for connections at the transfer station (by changing transport means) when using a particular connection:

$T_{w}=\sum\left(t_{i 2 d e p}-t_{i 1 a r r}\right)[\mathrm{min}]$

where:

$t_{i 2 d e p}$ is the departure time of the connecting train at the transfer station during $i$ changing

$t_{i 2 a r r}$ is the arrival time of the train to the transfer station during $i$ changing

- Achieving time $T_{D}$. This is the time from embarking when the travel trip begins, to the arrival of the train at the destination railway station. It is calculated as the sum of the average waiting time and transportation time:

$T_{D}=W_{i}+T_{p}[h]$

- Transportation speed $V_{P}$. This is given as a proportion of the distance travelled and time of transfer:

$V_{P}=\frac{L_{i}}{T_{P}}\left[k m \cdot h^{-1}\right]$

where:

$L_{i}$ distance route of relation

$T_{P}$ transportation time

- Achieving start-stop speed $V_{D}$. This is given as a proportion of the length of the relation and achieving time:

$V_{D}=\frac{L_{i}}{T_{D}}\left[k m \cdot h^{-1}\right]$

Transportation speed and achieving speed are important evaluation criteria for the quality of a particular connection relation. They are convenient indicators for comparing public transport link connections with individual transport.

\subsection{Relation evaluation}

After processing connections within single relations, it is necessary to evaluate the relation between tariff points on the 
Sample of connection assessment on the Bratislava-Prievidza relation (Friday)

Table 1

\begin{tabular}{|c|c|c|c|c|c|c|c|c|c|c|c|}
\hline $\begin{array}{l}\text { Connec- } \\
\text { tion } \\
\mathrm{Nr} . \\
-\end{array}$ & $\begin{array}{c}\text { Station } \\
\text { Bratislava } \\
\text { hl.st. } \\
\text { dep. } \\
\text { [hh:min] }\end{array}$ & $\begin{array}{c}\text { Station } \\
\text { Prievidza } \\
\text { arr. } \\
\text { [hh:min] }\end{array}$ & $\begin{array}{c}\text { Average } \\
\text { waiting } \\
\text { time } \\
\mathrm{W}_{\mathrm{i}} \\
{[\mathrm{h}]}\end{array}$ & $\begin{array}{c}\text { Con- } \\
\text { nect. } \\
\text { distance } \\
\mathrm{L}_{\mathrm{i}} \\
{[\mathrm{km}]}\end{array}$ & $\begin{array}{l}\text { Trans- } \\
\text { port } \\
\text { means }\end{array}$ & $\begin{array}{c}\text { Trans- } \\
\text { port } \\
\text { time } \\
\\
\mathrm{T}_{\mathrm{p}} \\
{[\mathrm{h}]}\end{array}$ & $\begin{array}{c}\text { Number } \\
\text { of } \\
\text { transfers } \\
\mathrm{N}_{\mathrm{p}}\end{array}$ & $\begin{array}{c}\text { Total } \\
\text { chan- } \\
\text { ging } \\
\text { time } \\
\mathrm{T}_{\mathrm{w}} \\
{[\mathrm{min}]}\end{array}$ & $\begin{array}{c}\text { Start-stop } \\
\text { achieving } \\
\text { time } \\
\mathrm{T}_{\mathrm{D}} \\
{[\mathrm{h}]}\end{array}$ & $\begin{array}{c}\text { Travel } \\
\text { speed } \\
\\
\mathrm{V}_{\mathrm{p}} \\
{\left[\mathrm{km} \cdot \mathrm{h}^{-1}\right]}\end{array}$ & $\begin{array}{c}\text { Start-stop } \\
\text { achieving } \\
\text { speed } \\
\mathrm{V}_{\mathrm{D}} \\
{\left[\mathrm{km} \cdot \mathrm{h}^{-1}\right]}\end{array}$ \\
\hline 1 & $6: 53$ & $9: 36$ & 6.25 & 158 & $\mathrm{R}$, & 2.72 & 0 & 0.00 & 8.97 & 58.16 & 17.62 \\
\hline 2 & $8: 03$ & $12: 20$ & 0.58 & 192 & R,Os,Os & 4.28 & 2 & 0.28 & 4.87 & 44.82 & 39.45 \\
\hline 3 & $10: 53$ & $13: 44$ & 1.42 & 158 & $\mathrm{R}$ & 2.85 & 0 & 0.00 & 4.27 & 55.44 & 37.03 \\
\hline 4 & $11: 53$ & $16: 14$ & 0.50 & 207 & R,Os,Os & 4.35 & 2 & 0.92 & 4.85 & 47.59 & 42.68 \\
\hline 5 & $13: 33$ & $17: 15$ & 0.83 & 207 & IC,Os,Os & 3.70 & 2 & 0.52 & 4.53 & 55.95 & 45.66 \\
\hline 6 & $14: 53$ & $17: 44$ & 0.67 & 158 & $\mathrm{R}$, & 2.85 & 0 & 0.00 & 3.52 & 55.44 & 44.93 \\
\hline 7 & $16: 03$ & 20:01 & 0.58 & 192 & $\mathrm{R}, \mathrm{Os}$ & 3.97 & 1 & 0.07 & 4.55 & 48.40 & 42.20 \\
\hline 8 & $18: 53$ & $21: 35$ & 1.42 & 158 & $\mathrm{R}$ & 2.70 & 0 & 0.00 & 4.12 & 58.52 & 38.38 \\
\hline \multicolumn{7}{|c|}{ Average per connection: } & 0.88 & 0.22 & 4.96 & 53.04 & 38.49 \\
\hline
\end{tabular}

network. For each relation, average values are calculated for all connections: number of transfers, transfer time, transportation speed, and achieving speed. It is also appropriate to verbally assess and justify the results of the calculations. The sample of evaluation of relation is introduced in Table 1 .

\section{Evaluation of the network connection}

For assessing connection quality on the network in terms of passengers, the multicriteria analysis (MCA) is suitable. The essence of this method is determining the importance weights of selected quality characteristics and the degree of customer satisfaction with their achievement. To determine the importance weights of quality characteristics, it is preferable to use the Sperling method where the weights of importance and degree of satisfaction are determined by assigning the number of points between 1 and 5 . The criterion with the greatest impact is determined by weight 5 , which means that the judge is the maximum number of points. The weights of other criteria are determined as a proportion of the weight of the importance of character with maximum impact.

The satisfaction rate of customers (passengers) $S$ is given as a proportion of the actual value and maximum value of quality [10], [11] and [14]:

$$
S=\frac{V N}{M H} \times 100[\%]
$$

where:

$V N$ perceived value of service quality

MH maximum value of service quality

Perceived value of service quality $V N$ :

$$
V N=\sum_{i=1}^{n} v_{i} \times S_{\text {ireal }}
$$

where:

$s_{i \text { real }}$ real level of customer satisfaction with i character

$v \quad$ weight of importance of the $i$ character

$n \quad$ quality character

The maximum value of quality is calculated according to the formula:

$M H=\sum_{i=1}^{n} v_{i} \times s_{i \max }$

where:

$S_{i \max }$ maximum degree of customer satisfaction with the i character

$v_{i} \quad$ weight of importance of the i character

$n \quad$ quality character

For investigating the impact of specific criteria, the statistical regression method can be applied. After determining the satisfaction level, we display the quality characteristics depending on the weight of importance and degree of satisfaction; hence, four quadrants are displayed. On the X-axis, we apply the resulting values reflecting the degree of customer satisfaction with the performance characteristics, and on the y-axis are plotted the resulting values of the weights that identify the importance of character.

\section{Case Study}

The research team elaborates on the case study to verify the proposed methodology. It was applied on connections on 


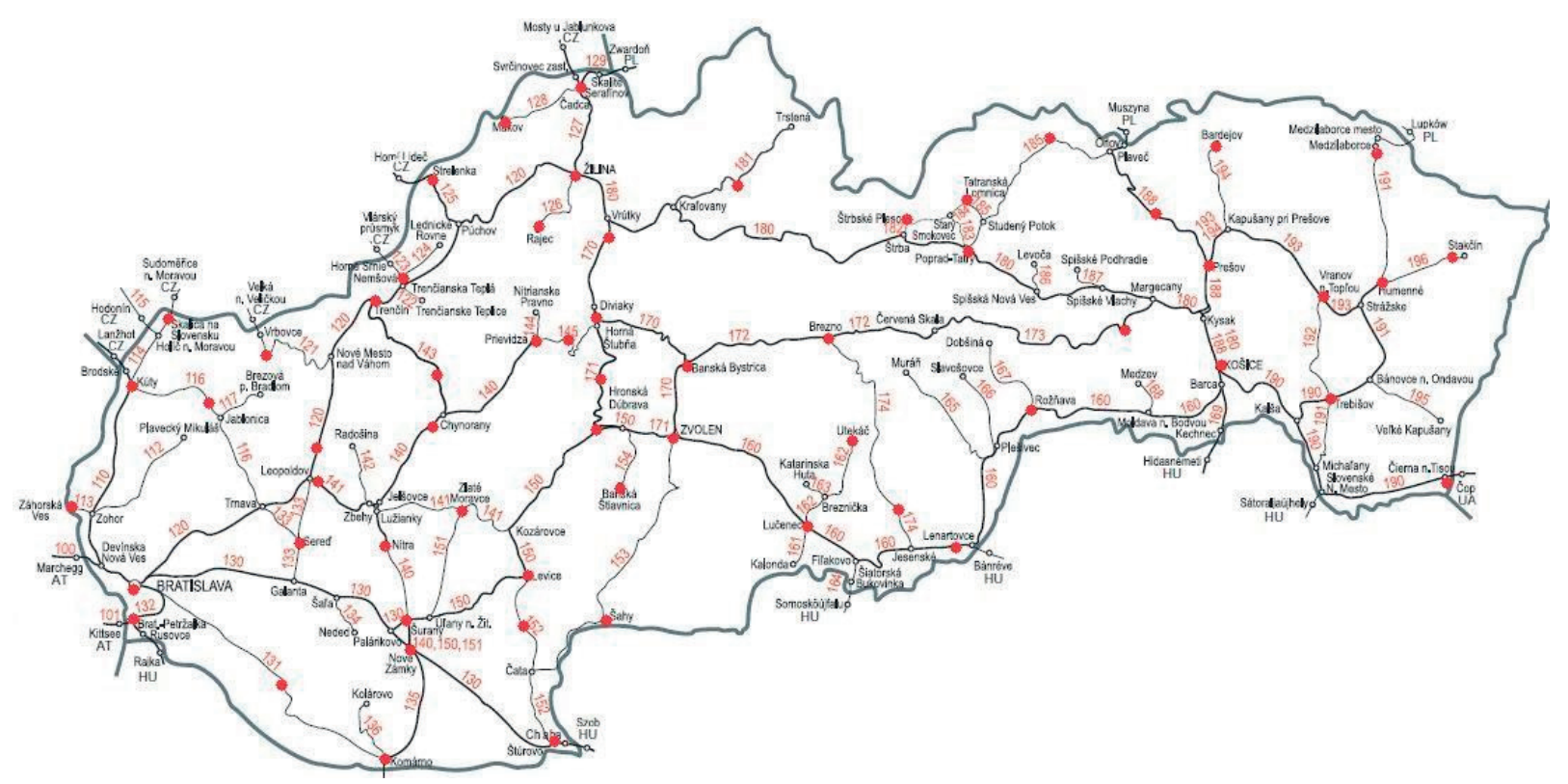

Fig. 1 Network map of ZSR showing the selected tariff points for assessing the quality of rail connections

the railway network of Slovak Railways (ZSR). We selected relations from the Bratislava main station to selected tariff points on the ZSR network (see Fig. 1). According to the proposed methodology and selection criteria, we identified 61 tariff points on the ZSR network. For the representative set of stations and stops, we selected first county centres, district towns over 20,000 inhabitants, junctions, and railway stations according to the criteria of geography and subsequently tourism centres so that each of the track lines in a set has at least one tariff point. The selected day of the week for the examination was Friday.

Results of the evaluation of connections on relations from the Bratislava main station according to average transportation speed, start-stop achieving speed, and average number of transfers (changing)

Table 2

\begin{tabular}{|c|c|c|c|c|c|}
\hline $\begin{array}{l}\text { From Bratislava } \\
\text { to destination }\end{array}$ & $\begin{array}{c}\text { Average travel speed } \\
\text { per relation } \\
\mathrm{V}_{\mathrm{p}}\left[\mathrm{km} \cdot \mathrm{h}^{-1}\right]\end{array}$ & $\begin{array}{l}\text { From Bratislava to } \\
\text { destination }\end{array}$ & $\begin{array}{l}\text { Start-stop achieving } \\
\text { speed } V_{D}\left[\mathrm{~km} \cdot \mathrm{h}^{-1}\right]\end{array}$ & $\begin{array}{l}\text { From Bratislava } \\
\text { to destination }\end{array}$ & $\begin{array}{l}\text { Average transfer } \\
\text { time } T_{w}[\mathrm{~min}]\end{array}$ \\
\hline Trencin & 89.58 & Kosice & 66.62 & Dunajska Streda & 0.00 \\
\hline Sturovo & 89.09 & Presov & 65.33 & Kosice & 0.00 \\
\hline Piestany & 78.34 & Poprad-Tatry & 64.48 & Poprad-Tatry & 0.00 \\
\hline Nove Zamky & 77.71 & Zilina & 62.92 & Zvolen os.st. & 0.00 \\
\hline Kuty & 77.70 & Trencin & 62.39 & Zilina & 0.00 \\
\hline Zilina & 77.45 & Trebisov & 60.41 & Ziar nad Hronom & 0.00 \\
\hline Kremnica & 53.16 & Makov & 34.74 & Brezno & 30.00 \\
\hline Prievidza & 53.04 & Dunajska Streda & 33.86 & Handlova & 32.63 \\
\hline Handlova & 51.96 & Sahy & 33.31 & Strelenka & 33.00 \\
\hline Utekac & 51.68 & Banska Stiavnica & 28.84 & Utekac & 33.80 \\
\hline Zahorska Ves & 48.98 & Zahorska Ves & 23.72 & Bardejov & 39.86 \\
\hline Dunajska Streda & 48.19 & Zlate Moravce & 18.60 & Kremnica & 55.75 \\
\hline Average per relation & 65.56 & Average per relation & 47.34 & Average per relation & 14.37 \\
\hline
\end{tabular}


In the timetable for 2013 [15] and under the proposed methodology, we retrieved for each relation all connections. For each connection, we set the value factors of the number of connections during the reporting day, the average waiting time $W_{i}$ of passengers, the distance route of relation $L_{i}$, transportation time $T_{p i}$, number of transfers, transfer time $T_{w i}$, achieving time $T_{D i}$, transportation speed $V_{P i}$, and achieving speed $V_{D}$.

Subsequently, we evaluated the relations. The most important evaluation criteria for the relations are listed in Table 2 that shows excerption of the start-stop achieving speed, average waiting time per relation, and average travel speed per relation. The listed factors characterises the transport service and are provided as outcome of an objective analyse of the offered connections according to the time table.

On the ZSR network, the highest average speed on modernized track lines from Bratislava to Trencin were direct connections. The start-stop speed was the highest on direct relations too, namely from Bratislava to Kosice, Presov, Zilina, and Nove Zamky. Just as quick are connections to Banska Stiavnica Zahorska Ves, and Zlate Moravce, indicating a slow connection in combination with long waiting times because of the small number of connections. The rate of average transfer time confirms this fact. The longest average waiting times is in the relations Bratislava-Kremnica, Bratislava-Bardejov, and Bratislava-Utekac.

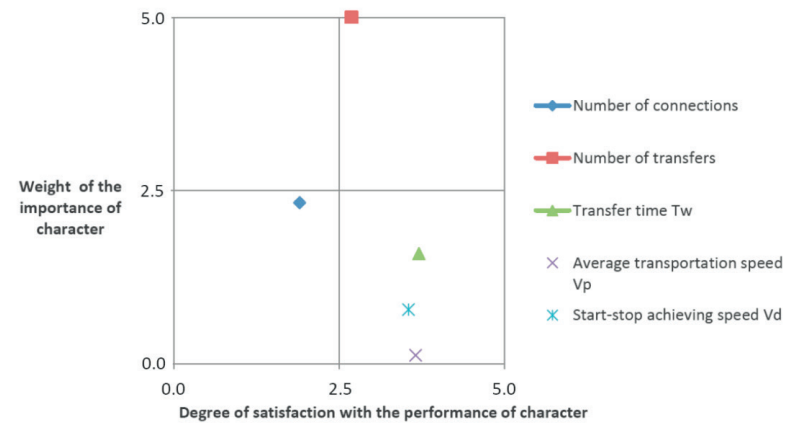

Fig. 2 The resulting values of quality researched characters

The set of relations was examined by using MCA and the Sperling methodology to determine the perceived value of quality services $V N$, the maximum value of quality services $M H$, and customer satisfaction rate $S$. As quality characteristics, we set the number of connections, number of transfers, transfer (changing) time, and achieving start-stop speed (see Fig. 2). The quality of the offered connections from Bratislava was rated as 26.99 points $(V N)$, the maximum assessment $M H=49.05$ points, and the customer satisfaction rate was $55.02 \%$. The impact of indicators value was determined based on the statistics of the number of passengers carried on individual relations.
The quality characters depending on weight importance and degree of satisfaction are shown in the chart. On the X-axis, we applied the values of the determined rates of customer satisfaction with performance criteria fulfilment. On the y-axis, we applied the resulting values of the identified weights of the character importance. The weight and degree of satisfaction were set in the range of 1 to 5 , where 1 was minimum importance and 5 maximum importance. The output of the case study is shown in Fig. 2. The most important criterion was the number of transfers (weight importance 5.0), which also has a relatively high level of customer satisfaction (importance 2.6). Passengers are least satisfied with the number of connections (1.59). This criterion does not, along with others, have a high weight of importance.

\section{Conclusion}

The issue of connectivity evaluation has not yet been sufficiently elaborated in the literature and is not used in practice where the connections from one station only are rated. This paper introduced the idea of a new evaluation methodology and included a case study on the network connection from the Bratislava main station to defined tariff points.

The proposed methodology covers the possibility of achieving any pair of tariff points in a selected railway network comprehensively. It not only offers an evaluation of the connectivity on a particular relation, but also objectively assesses the availability of connections between two selected tariff points based on quality indicators such as average number of transfers, average waiting time, average transportation speed, and average achieving speed. This enables us to evaluate the quality of the travel opportunities in this area by using selected indicators. Subsequently, using MCA allows us to evaluate the degree of customer satisfaction with selected quality attributes based on their importance. Ultimately, it is possible to examine the statistical dependence of the number of transported rail passengers by examining the quality connection on the network.

This methodology synthesizes knowledge from the theory of passenger transport and provides an evaluation of the connectivity and quality of constructed timetables for the entire rail network or only on selected rail networks.

It should be noted that the character of the current rail network loses due to gradual liberalization. Therefore, the significance of this methodology in the future will increase. The proposed methodology will be helpful for ministries of transport, regional public transport authorities, and other transport ordering bodies as well for integrated transport coordinators. The most important benefit of the proposal is that the evaluation is carried out in terms of the interests of passengers as users of a transport system that requires direct and fast connections. The resulting methodology can be applied in subsequent layouts of transport 
networks for public transport (Cenek et al., 2002, Kohani, 2013) [16] and [17].

The proposal will contribute to the creation of a competitive transport system that efficiently uses system resources. That is the plan of a Single European Transport Area within the purview of the White Paper "Roadmap to a Single European Transport Area - Towards a competitive and resource efficient transport system". This aims at the realization of an efficient and integrated system of mobility. The importance of the quality, accessibility, and reliability of transport services in the coming years may be even more important.

\section{Acknowledgement}

The paper is supported by the VEGA Agency under Project $1 / 0188 / 13$ "Quality factors of integrated transport system in the effective provision of public transport services in the context of globalisation" that is solved at the Faculty of Operation and Economics of Transport and Communications, University of Zilina.

\section{References}

[1] $\operatorname{COM}(2011)$ 144: White paper Roadmap to a Single European Transport Area - Towards a competitive and resource efficient transport system.

[2] EN 15140: Public passenger transport. Basic requirements and recommendations for systems that measure delivered service quality, 2006.

[3] EN 13816: Transportation - Logistics and services - Public passenger transport; Definitions, Determination of the performance goals and measuring of the quality on the service, 2002.

[4] Regulation (EC) No. 1371/2007 of the European Parliament and of the Council of 23 October 2007 on rail passengers' rights and obligations.

[5] ABRAMOVIC, B., BLASKOVIC ZAVADA, J., STEFICAR, S.: Railway as Backbone for Regional Passenger Transport, EUROZEL 2011, Zilina : University of Zilina, ISBN 978-80-263-0003-8.

[6] MOJZIS, V. et al.: Quality of Transport and Transportation Process (in Czech), Institut Jana Pernera, o.p.s. Pardubice, 2003, 176 p., ISBN 80-86530-09-4.

[7] MOJZIS, V., BULICEK, J.: Transfers in Passenger Public Transport (in Czech), Doprava, 2008. vol. 50, No. 5, pp. 13-15, ISSN $0012-5520$.

[8] NedeliaKova, E., MAJERCAK, J., NEDELIAK, I.: The Evaluation Methodology of Public Transport Logistic Chain in the Context of Qualitative Approaches to Regional Accessibility (in Slovak), Pozemne komunikacie a drahy, vol. 9, No. 1, 2013, pp. 53-58. ISSN 1336-7501.

[9] SULKO, P.: To the Connectivity Issue. Doprava a Logistika, vol. 7, No. 2.

[10] VONKA, J., DRDLA, P., BINA, L., SIROKY, J.: Passenger Transport (in Czech), Pardubice : University of Pardubice, 2001.

[11] SEDLAK, J.: Methodology Proposal for Rating of Connectivity of Train Passenger Services (in Slovak), Diploma thesis, University of Zilina, 2013.

[12] BUKOVA, B., NEDELIAKOVA, E., GASPARIK, J.: Business in Rail Transport (in Slovak), Bratislava : Iura Edition, 269 p., 2009 , ISBN 978-80-8078-248-1.

[13] PECENY, Z.: Passenger Transport (in Slovak), Zilinska univerzita : EDIS, 2000, ISBN 80-7100-781-1.

[14] LALINSKA, J., PECENY, L.: The Quality of Information in Supply Chain, LOGI 2012: conference proceedings, Brno : Tribun EU 2012, pp. 236-243, ISBN 978-80-263-0336-7.

[15] Time Table of Zeleznice Slovenskej republiky 2012/2013 (in Slovak), Bratislava, 2012.

[16] CENEK, P., JANACEK, J., JANOSIKOVA, L.: Location of Transportation Districts at Modelling of Transportation Processes in a Region, Communications - Scientific Letters of the University of Zilina, No. 1-2, 2002, pp. 5-9.

[17] KOHANI, M.: Designing of Zone Tariff in Integrated Transport Systems. Communications - Scientific Letters of the University of Zilina, vol. 15, No. 1, 2013, pp. 29-33, ISSN 1335-4205. 